Katsaus

\title{
Etnografian kerronnallisuus ja aika
}

\author{
Eino Heikkilä
}

$\mathrm{J}$ älkimodernia on luonnehdittu ajaksi, johon liittyy tarve tehdä identiteettityötä ja erityisesti tunnustaa, kertoa itsestä. Sosiologi Arthur W. Frankin mukaan esimodernina aikana tarinankerronnalla oli yhteisöllisiä funktioita, kuten tiedon siirtäminen eteenpäin jälkipolville, opettaminen myyttien avulla ja yhteisön sisäisen yhtenäisyyden ylläpitäminen. Jälkimodernina aikana sen sijaan on korostunut tarinankerronta yksilöllisenä projektina, jonka kautta yksilö käyttääääntään ja tuo omakohtaisen tarinansa julki. (Frank 1997, 4-7.) Näkemys tarinankerronnan muutoksista toimii taustana väitöskirjalleni, jossa tarkastelen tutkijuuden narratiivista rakentumista ja dialogista tiedonmuodostusta etnografisessa tutkimustekstissä. Monografiamuotoisen tutkimukseni aineisto käsittää seitsemäntoista 2010-luvulla julkaistua suomenkielistä etnografista väitöskirjaa, minkä lisäksi haastattelin viime vuonna osaa niistä tutkijoista, joiden väitöskirjaa olin lukemassa.

Kiinnostukseni kertomuksiin ja tarinoihin on vanhaa perua. Kirjastot ja antikvariaatit ovat olleet minulle lapsena ja nuorena tärkeitä rauhoittumisen paikkoja, joissa olen voinut keskittyä kirjoihin ja kertomuksiin, antautua niiden vietäväksi. Päästyäni yliopistoon lukemaan kansatiedettä huomasin, että tieteellisessäkin kirjallisuudessa esiintyy sellaista, mitä voisi kuvata kertomuksen imuksi. Tämän johdosta päädyin kiinnostumaan myös etnografisista tutkimuksista teksteinä: halusin ymmärtää, miten kerronnallisuus ilmenee niissä ja mikä merkitys kirjoittamisella on etnografisen tiedon muodostumisessa. Etnografian ja kirjoittamisen yhteyttä on tutkittu paljon erityisesti niin sanotun Writing Culture -liikkeen aiheuttamien keskustelujen pohjalta (ks. Clifford ja Marcus 1986; Geertz 1988; Van Maanen 1988), mutta sen sijaan vähemmän narratiivisesta näkökulmasta, jossa huomio kiinnittyy tekstien tapaan tuottaa merkityksiä ja tulkintoja (Ukkonen 2003).

Tässä katsauksessa tarkastelen teemoja, jotka ovat nousseet tutkimukseni edetessä esiin. Taustoitan ensin kertomusten ja kerronnallisuuden merkitystä kulttuurintutkimuksessa. Sen jälkeen esitän tutkimukseni pohjalta, miten etnografiaa voidaan tutkia narratiivisesti ja minkälaisia uusia näkökulmia sen kautta avautuu etnografiseen epistemologiaan. Silmäyksellä kirjallisuushistoriaan osoitan, että etnografisessa kerronnassa voidaan huomata vaikutteita eri kirjallisista tyylisuunnista ja että kysymys tekijyydestä säilyy siinä avainasemassa. Lopuksi hahmottelen filosofi Paul Ricœurin kertomusteorian avulla sitä, miten ajallisuus ilmenee etnografisessa tutkimusprosessissa ja -tekstissä ja mitä vaikutuksia ajallisuudella on tieteelliseen kerrontaan ja tutkijan näkymiseen tekstissä. Katsauksen tavoitteena on selventää 
etnografisen tiedonmuodostuksen ja narratiivisuuden välisiä yhteyksiä sekä toisaalta niihin liittyviä haasteita.

\section{Kerronnallisuus kulttuurintutkimuksessa}

Tarinankerronta tai kerronnallisuus nähdään nykyisin perustavanlaatuisena inhimillisen ajattelun ja mielen toiminnan ilmiönä. Ihmisen olemassaolo voidaan ymmärtää olemukseltaan kerronnalliseksi. (Silvasti 2001, 55.) Neurotieteilijä Mark Turner kutsuu kertomusta tai narratiivia inmisen mentaaliseksi työkaluksi, jota käytämme arjessa jatkuvasti (Turner 1996, 7). Kun käytämme kertomuksia ymmärtääksemme elämämme tapahtumia, ne auttavat meitä myös ymmärtämään itseämme; kertomukset ovatkin keskeisiä identiteetin rakentamisen välineitä (Miettinen 2006, 24-25). Ei siten ole yllättävää, että inmistieteissä on kiinnostuttu erilaisista narratiiveista, joiden kautta ihmiset merkityksellistävät kokemaansa.

Kirjallisuudentutkija Samuli Häggin mukaan kulttuurintutkimuksessa käytettävä narratiivinen tutkimusote on väljä metodologinen viitekehys, joka voi tutkimuskohteen lisäksi tarkoittaa myös tutkimuksen toteutustapaa. Hägg tekee eron tekstianalyyttisen narratologian ja kulttuurintutkimuksen parissa tehtävän narratiivisen tutkimuksen välillä ja esittää, että siinä missä edellinen viittaa systemaattiseen, käsitteelliseen ja tarkasti rajattuun tekstianalyysin menetelmään, jälkimmäinen on kiinnostunut ensi sijassa merkityksestä, identiteetistä ja sosiaalihistoriallisesta kontekstista. Tutkijan rooli ilmenee tutkimusperinteissä eri tavalla: narratologinen tutkimus ei useinkaan sisällä tutkijan aseman problematisointia, kun taas kulttuurintutkimuksen parissa tutkijan aseman reflektointi on perinteisesti ollut osa tutkimusta. Kulttuurintutkimuksessa ajatellaan myös aineiston muodostuvan lähtökohtaisesti tutkijan ja tutkittavan välisessä vuorovaikutuksessa. Häggin mukaan keskeiset erot narratologisen ja narratiivisen tutkimuksen välillä liittyvät tutkimuksen tavoitteisiin ja käytänteisiin. Narratologinen tutkimus kytkeytyy näennäisestä objektiivisuudestaan huolimatta eetokseltaan sanataiteen tutkimukseen ja pyrkii tuottamaan kiinnostavan taideteoreettisen tai filosofisen tulkinnan aineistostaan. Kulttuurintutkimuksessa kertomukseen suhtaudutaan sen sijaan tutkimusaineistona ja -otteena, jonka kautta voidaan pureutua yhteiskunnallisesti merkittäviin tutkimuskysymyksiin. (Hägg 2010, 117-119.)

Kertomusta tutkitaan nykyisin useilla tieteenaloilla. Kertomukselle annetut merkitykset voivat liittyä sanallisen esityksen määrätynlaiseen rakenteeseen tai muodoltaan vapaaseen ideaan, jopa niin että samassa tutkimuksessa esiintyy molempia näkökulmia. Folkloristi Kaarina Kosken mukaan verbaalisten kertomusten on myös ajateltu heijastavan niin sanottuja suuria kertomuksia ja kollektiivisia uskomuksia. Narratiivisessa filosofiassa on pohdittu lisäksi elämän ja kertomisen välistä suhdetta: onko elämän kokeminen jo lähtökohtaisesti kerronnallista, vai onko kertominen erillistä kokemuksesta? Koski määrittää neljä vastakkainasettelua kertomuksen käsitteeseen liittyen: koskeeko tutkimus yksittäisiä kertomuksia vai onko kertomus teoreettinen käsite; onko kertomus tutkimuskohde vai metodinen näkökulma; määritelläänkö kertomus muodon vai sisällön perusteella; ja onko kertomus konkreettinen ilmaus vai abstrakti, elämää jäsentävä merkityksenanto? Nämä kysymykset auttavat jäsentämään, missä merkityksessä kertomusta tutkimuksessa käytetään. (Koski 2007, 1-2.)

Klassinen narratologia, jonka juuret ovat venäläisessä formalismissa ja strukturalismissa, keskittyi kirjallisiin kertomuksiin yrittäen määritellä "kerronnan kielioppia". Narratologian rinnalle muodostui 1960-luvulta lähtien niin sanottu sosiolingvistinen traditio, joka tarkasteli 
kertomuksia tavallisessa arkipuheessa. Suomalaisessa folkloristiikassa on pitkään operoitu perinnelajien kanssa, mutta viimeisten vuosikymmenten aikana huomio on kiinnittynyt enemmän muistitiedon ja elämäkerrallisen kerronnan tutkimiseen. Tällöin kertomisen voi määritellä esimerkiksi identiteetin rakentamisen välineeksi ilman, että olisi tarvetta määritellä kertomuksen muodon tai sisällön kriteerejä. Narratiivisuus viittaa siihen, että tekstissä (tai puheessa tai esityksessä) on tunnistettavissa joitain kertomukselle tyypillisiä piirteitä, kuten että siinä on kertomisen arvoinen aihe ja sen rakenne on ajallisesti jäsentynyt. Kosken mukaan historiantutkimuksessa kertomusta käsitellään ennemmin tietoteoreettisena kuin lingvistisenä kysymyksenä. Tällöin kertomustieto ja tieteellinen tieto ajatellaan usein toisilleen vastakkaisiksi. Niin sanottujen suurten kertomusten murruttua postmodernismin myötä historiantutkimusta onkin alettu korostaa tosiasioihin perustuvana tieteenä erotuksena tulkinnallisista ja tiedoltaan värittyneistä kertomuksista. Toisaalta narratologit ovat olleet huolissaan siitä, että nykyisin kertomukseksi voidaan kutsua melkein mitä tahansa viestiä, selitystä tai teoriaa. Tämä hämärtää kerronnan ja muun kaltaisen viestinnän välistä eroa, jolloin narratiivisuuden tieteellinen selitysvoima voi kyseenalaistua. (Koski 2007, 2, 5 , 7-8.)

Tutkijan suhdetta tarinankerrontaan on tavallisesti lähestytty ulkoapäin: tutkija on kiinnostunut muiden ihmisten elämäntarinoista ja kertomuksista. Tässä yhteydessä käännän katseen kuitenkin tutkittavasta ilmiöstä tutkijaan, jolloin kysymys kuuluu, minkälaisia kertomuksia tutkija itse aineistonsa pohjalta tuottaa ja miten nämä kertomukset rakentuvat. Teoreettinen lähtökohtani on narratiivisessa kulttuurintutkimuksessa ja erityisesti Paul Ricœurin kertomusten temporaalisuutta koskevassa ajattelussa, jota sovellan etnografisten tutkimustekstien tarkasteluun.

\section{Narratiivisuus ja etnografinen epistemologia}

Katsauksessa tarkastelen etnografista tekstiaineistoani narratiivisesti, mikä tarkoittaa että tulkitsen sitä määrättyjen kertomukseen liitettyjen piirteiden avulla. Narratiivi ja narratiivisuus viittaa tällöin tekstin ominaisuuksiin, ja kertomus on puolestaan teoreettinen yläkäsite, joka ohjaa sitä mihin kiinnitän lukiessa huomiota. Yhteiskuntatieteilijä Sonja Miettinen määrittelee kertomuksen neljän piirteen avulla: tapahtumallisuuden, ajallisuuden, juonellisuuden ja henkilöisyyden. Ensinnäkin kertomus kuvaa tapahtumia, ja yksittäiset tapahtumat ovat rakennuspalikoita, joista kertomukset muodostuvat. Kertomukselle on ominaista myös ajallisuus: siinä esitetty tapahtumasarja sijoittuu jollekin ajanjaksolle. Juoni puolestaan sitoo yksittäiset tapahtumat yhteen merkitykselliseksi kokonaisuudeksi, jossa on alku, keskikohta ja loppu. Yksittäiset tapahtumat saavat merkityksensä vain osana juonta, jonka etenemistä ne ohjaavat. Juonen ei tarvitse edetä kovinkaan loogisesti, vaan juonen avulla voi punoa kertomukseen myös sattumia, odottamattomia käänteitä ja konflikteja, jotka eivät sinällään edistä tarinaa. Lisäksi kertomukseen kuuluvat olennaisesti henkilöt. Kertomukset kuvaavat sitä, mitä inmiset tekevät ja mitä heille tapahtuu tämän seurauksena. (Miettinen 2006, 25.)

Kulttuuriantropologi Merlijn van Hulstin mukaan arkipäiväisissä kertomuksissa selostetaan, mitä tapahtui jossain tilanteessa tai ympäristössä. Kertomusten määräävä piirre on siten se, että jotain on tapahtunut, ja tästä tapahtuneesta on muodostettu kertomus. Usein kertomuksissa keskitytään ihmisten aikomuksiin ja toimintaan. Tilanne pitää sisällään ajan ja paikan ulottuvuudet: jotain voi tapahtua vain ajan ja materiaalisten olosuhteiden puitteissa. Aristotelesta seuraten voidaan olettaa, että kertomuksella on alku, keskikohta ja loppu, 
mutta käytännössä tarinankertoja voi kertoa kertomuksesta vain osan jättäen esimerkiksi tilanteen kuvailematta. Kertomukseen sisältyy lisäksi yleensä juoni, joka antaa kerrotuille tapahtumille merkityksen: miksi tapahtui niin kuin tapahtui ja mitä tapahtunut merkitsee. Tarinankertoja voi juonellistamisen kautta esimerkiksi korostaa tai vastaavasti mitätöidä jonkun toimijan merkitystä tapahtumakulun kannalta. Juonellistaminen voi olla tarkoitushakuista, jolloin kertoja pyrkii tuottamaan tapahtumista tulkinnan, joka esittää hänet tai hänen edustamansa ryhmän edullisessa valossa. Van Hulstin mukaan tarinankerronta on sosiaalista toimintaa, jossa kerrotaan yhdelle tai useammalle henkilölle mitä on tapahtunut. Kertomuksilla on monenlaisia tehtäviä yhteisössä: ne antavat tietoa tapahtumista ja tulkitsevat tapahtuneen merkitystä, ja niiden kautta voidaan ohjata, opettaa tai varoittaa muita ihmisiä. (Van Hulst 2020, 99-100.)

Jo etnografisen tutkimustekstin pintapuolinen lukeminen osoittaa, ettei kyseessä ole tavanomainen kertomus siinä mielessä kuin arkikielessä kertomukseen viitataan. Sanana kertomus liitetään edelleen herkästi fiktiivisten tekstien ja kaunokirjallisuuden yhteyteen. Ajatus etnografiasta yhdenlaisena kirjallisuuden muotona ei kuitenkaan ole uusi, vaan aihetta ovat nostaneet esiin monet postmodernit kirjoittajat ja antropologit erityisesti 1980-luvun Writing Culture -liikkeen myötä (ks. Clifford ja Marcus 1986). Liike ja sen ympärillä käyty keskustelu viitoittivat tietä uudenlaiselle, refleksiiviselle tavalla tehdä etnografiaa, joka on tietoinen kolonialistisesta perinnöstään ja kulttuuristen ilmiöiden representointiin liittyvistä ongelmista. Antropologi John Van Maanen onkin sanonut etnografisen kenttätyön olevan pikemminkin tulkitsevaa kuin havainnoivaa tai kuvailevaa toimintaa (Van Maanen 1988, 93). Tässä painotuksessa etnografian ydin on siinä, miten tutkija tutkimusprosessin eri vaiheissa tulkitsee aineistoaan tietoisena omasta positiostaan tutkijana ja tulkintojen tekijänä (ks. Fingerroos 2003).

Tulkitseva ja refleksiivinen tutkimustyö kiteytyy kirjoittamisen osalta kysymykseen siitä, miten ja millä tavoin tutkija representoi tutkimuskohdettaan. Tähän liittyen on myös puhuttu antropologian "representaation kriisistä", jolla viitataan niihin ristiriitoihin, joita tutkija kokee pyrkiessään tuottamaan uskottavan kirjallisen kuvauksen tutkittavasta ilmiöstä (Gould 2016, 16). Toisaalta, kuten esimerkiksi Amanda Coffey on huomauttanut, etnografiaa harjoittavissa tutkijayhteisöissä on aina esiintynyt jännitteitä esimerkiksi positivistisen ja modernistisen suuntauksen välillä - kriisi ei siten välttämättä anna koko kuvaa etnografian muutoksesta (Coffey 1999, 9-10). Jos kuitenkin hyväksytään se, että etnografia on mitä suurimmassa määrin kirjoittamista (Atkinson 1992, 5) ja että etnografinen teksti on kulttuuria tai sen osaa käsittelevä kirjallinen kuvaus, jota ohjaavat määrätyt konventiot (Van Maanen 1988 , 1), herää kuin itsestään kysymys siitä, missä suhteessa kirjoitettu on koettuun ja elettyyn todellisuuteen. Kysymys ei kuitenkaan liity vain representaation ongelmiin tai niihin tyylikeinoihin ja -lajeihin, joita etnografit ovat kirjoittaessaan soveltaneet (ks. Van Maanen 1988), vaan kysymys on ennen kaikkea epistemologinen eli tiedon muodostumista koskeva.

Etnografian epistemologinen perusta ei ole selvärajainen, sillä etnografista tutkimustapaa on sovellettu jo pidempään eri tieteenaloilla - kuten antropologiassa, sosiologiassa, folkloristiikassa ja kansatieteessä - joiden kautta siihen on suodattunut erilaisia tietoteoreettisia näkemyksiä. Väitöskirjani aineistossa voidaan kuitenkin havaita selvästi, että ne ovat pääosin epistemologisesti sosiaalisesta konstruktionismista ammentavia. Konstruktivistisessa tietoteoriassa tieto nähdään kielellisesti ja diskursiivisesti tuotettuna, sosiaalisesti paikantuneena ja kulttuurisidonnaisena ilmiönä. Tietoa ei tässä mielessä ole sosiaalisten ja kielellisten 
käytäntöjen ulkopuolella. Tähän liittyy myös vahvasti etnografinen ajatus yhteisestä tiedosta: sekä tutkija että tutkittavat osallistuvat tiedon muodostamisen prosessiin. Toinen, edelliseen vahvasti sitoutuva epistemologinen juonne aineistossa on peräisin feministisestä tieteenkritiikistä. Sen mukaan tutkimus ei voi koskaan olla "objektiivista", näkökulmatonta tai riippumatonta tutkimuskohteestaan. Tutkimuksen tuottama tieto on sen sijaan aina osittaista ja valittuun näkökulmaan sidottua, jolloin tiedon paikantumisen julkituominen on keskeistä koko tutkimuksen arvioinnin kannalta. Feministiteoreetikko Donna Haraway onkin todennut, että tieteen niin kutsuttu objektiivisuus edellyttää tuotetun tiedon tarkkaa paikantamista (Haraway 1991, 190). Tiedon paikantaminen toteutuu etnografisessa tutkimustekstissä refleksiivisyytenä, jonka kautta tutkija tuo esiin tutkimuksensa subjektisidonnaisuuden (Fingerroos 2003).

\section{Etnografia kertomuksena}

Etnografisen tekstin narratiivisen tarkastelun lähtökohtana on havainto etnografian ja muiden kertomustyyppien välisistä yhtäläisyyksistä. Etnografioissa esiintyy tapahtumia, ajallisuutta, juonirakennetta ja henkilöitä, joita voidaan pitää kertomuksen yleisinä piirteinä. Niissä myös usein hyödynnetään kaunokirjallisia keinoja esimerkiksi rakentamalla tarinallisia kaaria ja käyttämällä erilaisia kirjoittamisen tyylilajeja, kuten runoutta ja tuokiokuvia, elävöittämään kerrontaa sekä herättämään lukijoissa tunteita (Elliott ja Culhane 2017). Niissä voidaan käyttää valokuvia ja muuta visuaalista materiaalia tukemaan tekstin narratiivia (Bagayoko ja Tawah 2014). Etnografian ja kaunokirjallisten kertomusten vertailu ei toisaalta ole ongelmatonta, sillä vaikka niissä käytetään samoja välineitä, niiden suhde kerrottuun on erilainen. Tutkimustekstissä lähtöoletus on, että teksti heijastelee sitä, mitä tapahtui ja mitä tutkija koki. Sanotun oletetaan vastaavan tekstin ulkopuolisia tapahtumia, sillä etnografista tutkimusta luetaan siksi, että se antaisi uutta tietoa ja ymmärrystä sosiaalisista ilmiöistä (Van Maanen 1988, 1, 4). Lisäksi minä-muodon oletetaan tutkimustekstissä viittaavan kirjoittajaan itseensä, ellei lauseyhteys muuta ilmaise. Kaunokirjallisuuden kohdalla suhde kerrottuun on moniulotteisempi, ja siinä ilmenevät ne monenlaiset käsitykset, joita kirjallisuuteen on ajan saatossa liitetty.

Kirjallisuustieteilijä Liisa Saariluoman mukaan antiikista 1700-luvun puoliväliin kirjallisuus käsitettiin yhteiseksi varannoksi. Aiheet, teemat ja ilmaisumuodot pysyivät samoina teoksesta toiseen. Kirjallinen teos ei periaatteessa ollut kenenkään yksityisomaisuutta, vaan teokset kuuluivat yhtenevään traditioon, jossa käytettiin samoja ilmaisukeinoja. Aiheet saatiin usein antiikin myyteistä tai Raamatusta. Länsimaisen kirjallisuuden murros tapahtui 1700-luvun jälkipuoliskolla, jolloin hylättiin klassinen paradigma. Uusi, moderni paradigma saa ilmauksensa romantiikassa, jonka mukaan taide ei synny traditiosta vaan elämästä, yksityisen ihmisen kokemuksista. Teoksen syntytausta ei näin ollen ole kirjallisessa traditiossa, vaan taiteilijan persoonallisuudessa. Omaperäisyydestä tulee taiteen suuruuden mitta, oikea taiteilija luo itsestään käsin. 1800-luvun kirjallisuuden realistinen suuntaus ei kuitenkaan hylkää romantiikan ajatusta taiteilijanerosta, vaan muuntaa hänet eräänlaiseksi tiedemieheksi, jonka pyrkimyksenä on kuvata aikansa yhteiskuntaa ja ihmisiä mahdollisimman todenmukaisesti. Empiristisen tietoteorian mukaan todellista on se, mikä on tässä ja nyt havaittavissa. Realistinen kirjailija tutkii todellisuutta itsenäisesti, traditioista välittämättä. Realismissa tavoitteena on mahdollisimman ehyt illuusiovaikutus: kuvauksen tulee olla niin todenmukaista että lukija ikään kuin tuntee todellisuuden läsnäolon. (Saariluoma 1998, 7.) 
1900-luvun modernismissa kyseenalaistui yhteisen todellisuuden olemassaolo ja sen sijaan painottui subjektiivinen kokemus. Samalla kielen läpinäkyvyys kuvauksen välineenä asettui kyseenalaiseksi. Kuitenkin vasta postmoderni kirjallisuus 1950-luvulta alkaen problematisoi kirjailijan autenttisuuden tekstin lähteenä; tekstiä ei nähty enää kirjailijan itseilmaisuna vaan tekstuaalisessa avaruudessa liikkumisena. Tekstien ajateltiin lähtökohtaisesti rakentuvan toisten tekstien varaan. Jälkistrukturalismin myötä kirjallisuuden ulkopuolinen todellisuus puolestaan asettui kyseenalaiseksi; ajateltiin että todellisuus tulee käsitettäväksi vain kielen välityksellä ja on jokseenkin naiivia puhua todellisuudesta sinänsä, ilman kieltä. Äärimmillään tämä ajattelu johtaa kuitenkin "kielen vankilaan". Diskursseista, eli tavoista käyttää kieltä, tulee silloin itsenäisiä todellisuuksia, joiden pätevyyttä ei voida arvioida, sillä mitään niiden ulkopuolista, riippumatonta viittauspistettä ei ole olemassa. Nykyisessä (osittain) jälkistrukturalismin jälkeisessä tilanteessa, jota määrittävät muun muassa Foucault'n diskursiivisen vallan analyysi ja feministinen kritiikki, kirjallista tekstiä on taas lupa arvioida suhteessa ei-kirjalliseen todellisuuteen. Kirjailija on samalla saanut subjektin asemansa takaisin; vaikka hän on kulttuurisena toimijana erilaisten diskurssien vaikutuksen alainen, hän voi osaltaan myös toimia diskursiivisia malleja vastaan ja muuttaa käsitystä todellisuudesta. (Saariluoma 1998, 8-10.)

Etnografiassa voidaan nähdä jälkiä erilaisista kirjallisuuskäsityksistä, mutta varsinkin realismista ja toisaalta jälkistrukturalismin jälkeisestä tilanteesta. Etnografian realistinen pohjavire on ilmeinen: tutkija pyrkii kuvaamaan tutkimaansa kenttää mahdollisimman todenmukaisesti, empiiriselle aineistolleen uskollisesti. Samaan aikaan jälkistrukturalismin jälkeiset ajatukset tutkijan (ja tiedon) kulttuurisesta paikantumisesta ja tiedon sosiaalisesta rakentumisesta ovat tulleet mukaan etnografian epistemologiseen valikoimaan. Roland Barthesin tunnettu teesi "tekijän kuolemasta", jonka mukaan kirjailija on menettänyt auktoriteettinsa sanoa mitä teksti tarkoittaa, on suhteessa etnografiaan ambivalentti. Yhtäältä etnografia edellyttää tutkijaminän kokonaisvaltaista läsnäoloa aineiston muodostuksessa, tulkinnassa ja tutkimusta kirjoittaessa (Gould 2016, 15; Hämeenaho ja Koskinen-Koivisto 2014, 9), mutta toisaalta etnografiseen tiedontuotantoon sisältyy myös vahvasti ajatus dialogisuudesta ja vastavuoroisuudesta (Coffey 1999, 54-55; Raunola 2010). Kysymykseen tekijyydestä liittyy näin ollen ilmeisiä jännitteitä. Osa jännitteistä juontuu nähdäkseni siitä, että etnografiaa tehdään tätä nykyä useista epistemologisista lähtökohdista: tutkimus voi perustua esimerkiksi geertziläiseen ajatukseen kulttuurin "tiheästä kuvauksesta", hermeneutiikkaan sekä konstruktivistiseen näkemykseen tiedon sosiaalisesta rakentumisesta ja siihen liittyvistä neuvotteluista.

\section{Etnografian aika}

Tutkimuksessani narratiivisuus näyttäytyy tapana silloittaa etnografiseen tiedontuotantoon sisältyviä jännitteitä ja ristiriitoja. Narratiivisuuden kautta tutkimustekstin eri ainesosat ja ajalliset kerrostumat saadaan sovitettua yhteen koherentiksi kertomukseksi. Hedelmällinen tapa eritellä narratiivisuuden merkitystä etnografiassa avautuu Paul Ricœurin kerronnan ja ajallisuuden yhteyttä käsittelevässä teoretisoinnissa. Ihmisen kokemusta määrittää tunne ajasta ja sen etenemisestä, mutta mitä aika oikeastaan on ja miten sitä voidaan lähestyä? Ricœurin mukaan historiankirjoituksessa tai fiktiivisissä tarinoissa harvoin kyseenalaistetaan ajan käsitettä; niissä pikemminkin otetaan annettuna se, että tarina ja sen tapahtumat etevät ajassa. Tässä "temporaalisessa kehyksessä" normaalina pidetty aika esiintyy peräkkäisinä nyt-hetkinä. Toisaalta ajan kokemuksellisuutta tutkivassa fenomenologiassa jätetään 
huomiotta narratiivisuus tapana artikuloida kokemustamme ajasta. Ricœur esittääkin, että juuri erilaisten narratiivien kautta temporaalinen, ajallinen olemassaolo saa parhaan sanallisen ilmaisunsa. (Ricœur 1991, 99.)

Ricœurin aikaa käsittelevä filosofia lähtee kirkkoisä Augustinuksen aikaa koskevista pohdinnoista. Aika näyttää paradoksilta, koska mitattavuudestaan huolimatta sitä ei oikeastaan ole olemassa - menneisyys on ohi, tulevaisuutta ei ole vielä ja nykyhetki ei seisahdu, vaan pakenee tarkastelua. Ricœur esittää, että kosmologisen eli mitattavan ja toisaalta koettavan, inhimillisen ajan välillä on ristiriita, jota inminen yrittää ratkaista. Tapa sovitella tätä eri aikojen välistä ristiriitaa on juonellistaminen (engl. emplotment), jossa toisistaan erilliset tapahtumat yhdistetään yhtenäisiksi tarinoiksi. Juonellistaminen on Ricœurin mukaan inhimillinen perustoiminto, jonka avulla inminen pyrkii luomaan jatkuvuutta ja sointuvuutta kokemaansa. Kertomukset eivät niinkään jäljittele sosiaalista todellisuutta, kuten korrespondenssiteoriassa ajatellaan, vaan auttavat jäsentämään ja ymmärtämään sitä. Sekä fiktiiviset että tosiasioihin perustuvat, historialliset kertomukset ovat siten inhimillisen ajan juonellistamista, vaikka erilaisten kertomusten aikakäsityksissä on myös eroja. Ricœurin kertomusteoria pohjautuu hänen omintakeiseen kielifilosofiaansa, jonka mukaan kieli kohdistuu aina johonkin. Kielellä, ja siten myös kertomuksella, on viittauskohde eli referentti itsensä ulkopuolella. (Ricœur 1984, 7-16; ks. myös Hallila 2008, 27.) Ajan osalta tämä tarkoittaa, että kertomuksessa ilmenevä aikakäsitys on aina jossain yhteydessä koettuun aikaan, ja toisinpäin: kokemus ajasta kirjoittautuu kertomuksiin.

Etnografian tarkastelussa on tärkeää huomioida se, että tutkimusprosessi kokonaisuudessaan vie paljon aikaa, useita vuosia, ja että tämä (käytetty) aika ilmenee kirjoitetussa tekstissä tietyllä tavalla. On tyypillistä, että aikaa kuluu paljon paitsi etnografiseen kenttätyöhön ja siihen liittyviin käytänteisiin myös aineiston analyysiin ja kirjoittamiseen. Kirjoittaminen itsessään on etnografiassa monivaiheinen prosessi, jossa irrallisista muistiinpanoista ja tekstipätkistä vähitellen kootaan jotain yhtenäistä. Eräs tapa hahmottaa ilmiötä, jota kutsun "etnografian ajaksi", on pitää sitä muistiin liittyvänä asiana: kirjoittamisen hetkellä kuvatut tapahtumat ovat menneessä ajassa, joka välittyy kirjoittajalle muistin kautta. Myös preesensmuotoiset kenttämuistiinpanot ovat kuvauksia menneistä tapahtumista, vaikka asiat olisivat tapahtuneet juuri äsken. Etnografian aika on tässä merkityksessä muistin aikaa silloin kun tekstissä viitataan tutkijan tai tutkittavien toimintaan ja puheeseen. Valaisen tätä esimerkillä kansatieteilijä Miia-Leena Tiilin väitöskirjasta, joka käsittelee ammattilaisuuden rakentumista Suomenlahden merivartiostossa. Katkelma on kirjoittajan kenttäpäiväkirjasta.

Palaan ampumaradalta, törmään Seppäseen ja muuhun porukkaan. Ovat siviileissä [arkivaatteissa], tekevät hyväntuulisina lähtöä illanviettoon. Kutsuvat minua taas mukaansa ja päätän sittenkin hypätä remmiin. Tunnelma on helppo, syödään pitsaa ja juodaan olutta, puhutaan niitä näitä. (Tiili 2016, 52.)

Otteessa tutkija-/kertojaminä on selkeästi yksi henkilöistä: hän osallistuu vuorovaikutukseen muiden kanssa, syö pizzaa ja juo olutta. Lyhyt ja tiivis lauserakenne luo tunteen tilanteen akuuttisuudesta, siitä, että tilanne on käynnissä kertojan kuvaamalla hetkellä. Preesensmuodon käyttäminen ei kuitenkaan tarkoita, että kirjoittaja itse olisi kirjoittanut päiväkirjaa tapahtumien keskellä, vaan se on ehkä osittain tiedostamaton tyylikeino, jonka kautta lukijalle välitetään kuva yhdestä hetkestä kentällä. Tiili kertoo väitöskirjassaan, että kenttäpäiväkirjaotteet on kirjoitettu muistiinpanojen pohjalta ja että impressionistisen kerronnan avulla hän on halunnut välttää näennäisobjektiivisen viranomaiskielen. Kenttäpäiväkirjassa 
preesenmuodossa etenevä kerronta on siis muodostettu jälkikäteen muistiinpanojen pohjalta, mikä osaltaan alleviivaa tekstin ajallista kerrostuneisuutta. Vertailukohdaksi voidaan ottaa haastattelupuhe, jota tutkija käyttää tutkimuksessaan. Haastattelu on tapahtunut aiemmin, mutta tallennuksen ansiosta haastateltavan täsmälliset sanat ovat todennettavissa, ja suoran lainaamisen kautta ne tuodaan osaksi tekstin tämänhetkisyyttä. Samoin kun tutkija lainaa toisen tutkijan ajatuksia joko suoraan tai epäsuorasti jostain teoksesta tai julkaisusta, alkuperäislähteen ajatus sulautuu osaksi uuden tutkimuksen kerronnan aikaa.

Esimerkit osoittavat, että vaikka kuvaukset kentän tilanteista ja tapahtumista voidaan havaita muistinvaraisiksi, etnografiassa on poikkeuksetta myös aineksia, jotka ovat ajallisesti ambivalentteja: ne ovat tapahtuneet menneisyydessä, mutta samalla ne ovat, kirjoittamisen hetkeen ja tilanteeseen tuotuina, tämänhetkisiä ja akuutteja. Tutkijan analyysissa kentän tapahtumat, tuotettu aineisto ja toisaalta se, mitä aiemmin on sanottu ja kirjoitettu, tuodaan yhteen ja niiden pohjalta rekonstruoidaan uutta tietoa. Etnografian ajallinen monimuotoisuus ilmenee myös vähemmän eksplisiittisesti. Tutkimustekstin kertojaminä voi esimerkiksi kertoa, missä merkityksessä hän käyttää tiettyä käsitettä, ja viitata teoreettisiin keskusteluihin, mutta lukijalle ei useinkaan kerrota, milloin tutkija on tehnyt valintansa käsitteen käytön suhteen. Kun ajalliset viittaussuhteet eivät käy tekstistä ilmi tai ne ilmaistaan epämääräisesti, kertoja henkilönä alkaa väistyä taka-alalle ja kerronnan kytkös aikaan ja paikkaan häviää.

Hahmottelemaani etnografian aikakäsitystä voi verrata siihen, mitä Tuija Saresma kirjoittaa omaelämäkerran ajasta. Omaelämäkerrassa tarina suuntautuu ajassa eteenpäin, mutta toisaalta siinä esiintyy myös pysähtelyä, toistamista ja sivupolkuja. Kerrontaan tulee hetkiä, jolloin tarina ei etenekään: oivalluksen, punctumin, ilmestyksen tai inmetyksen hetkiä, jotka katkaisevat kertomuksen virtaamisen. Vaikka omaelämäkerta ilmenee liikkeenä, se on Saresman mukaan samalla seisahdus ja yhteenveto elämän merkittävistä hetkistä ja tapahtumista. Sen kirjoittaja "kirjoittaa itseään todelliseksi" tietoisena siitä, että hänen elämänsä jatkuu kirjoittamisen jälkeenkin. (Saresma 2007, 69-71.) Tutkimuskirjallisuutena etnografian fokus on uuden tiedon tuottamisessa, mutta myös siinä voidaan havaita hetkiä, jolloin kerronta pysähtyy ja tutkija-kertoja ikään kuin astuu taaksepäin ja reflektoi aiemmin sanottua. Kertoja voi liikkua kerronnan eri rekistereissä, jotka puolestaan sitoutuvat erilaisiin ajan määreisiin.

Vaikka lukija ymmärtää, että etnografian kirjoittaminen on tapahtunut tiettyinä ajankohtina ja määrätyissä tilanteissa, tekstissä aikatasot voivat vaihdella, liukua ja sulautua yhteen. Aika voi myös liueta niin, ettei se ilmene kerronnassa juuri mitenkään. Esimerkiksi teoreettinen ja metodologinen keskustelu käydään yleensä ikään kuin temporaalisen olemassaolon ulkopuolella, siinä missä kenttätyötä ja -oloja kuvatessa ajallisuus, ja sitä myöten myös kehollisuus, ovat kerronnassa selvästi läsnä. Aika tuo tekstiin kokemuksen itsestä ja ympäristöstä sekä narratiivin, jossa tapahtumat liittyvät toisiinsa juonen avulla, kun taas ajan puuttuessa on vain ajatuksia ilman narratiivia. Tämä tarkoittaa, että ajallisuudessa ilmenevät katkokset muuttavat etnografista tekstiä vähemmän kerronnalliseen suuntaan.

Etnografinen narratiivi ei ole ajallisesti koherentti, vaan että se rakentuu sekä tarkoista että summittaisista ajanmääreistä, jotka eivät noudata kronologista järjestystä, vaan paremminkin tekstin sisäistä logiikkaa. Kerronnan ajassa voi myös esiintyä katkoksia. Ajallinen monimuotoisuus heijastaa niitä haasteita, joita antropologi Richard Wiik on tunnistanut etnografisen tiedonmuodostuksen kuvaamisessa. Hänen mukaansa esimerkiksi analyysin taustalla 
ollutta ajatteluprosessia ei kuvata tarpeeksi ja metodeista kerrotaan epämääräisesti turvautuen metaforiin kuten "etnografinen katse". Tutkimuksesta ei usein selviä, miten hajanaisesta aineistosta on tehty tutkimusteksti, tieteellinen narratiivi. (Wiik 2011, 23-24.) Tämä kritiikki kannattaa ottaa tosissaan ja miettiä, miten lisätä etnografisen tutkimusprosessin läpinäkyvyyttä. Narratiivisen näkökulman kautta voidaan hahmottaa paremmin ajallisuuden ja kerronnan välisiä yhteyksiä ja siten valaista etnografisen tiedonmuodostuksen solmukohtia. Tutkimuksen narratiivisuus tulee myös nähdä laajempana epistemologisena ongelmana kuin tähän asti etnografiassa on tehty.

Clifford Geertzin (1988) ajatusta siitä, että etnografinen tutkimusprosessi jakautuu merkittävästi kahteen osaan - kenttätyöhön ja kokemuksiin tutkittavien parissa ("being there") sekä toisaalta kirjoitustyöhön ja tutkimuksen koostamiseen kentältä paluun jälkeen ("being here") - voidaan lähestyä myös kysymyksenä siitä, mitä ajallisuus merkitsee tutkimuksen eri vaiheissa ja miten se kirjoittuu osaksi tekstin narratiivia. Kerronnallisesti ilmaistu ajallisuus tarjoaa yhden näkökulman ymmärtää, miten eletty kokemus suodattuu tietynlaiseksi kirjoitukseksi. Kenttätyö on paitsi paikkaan kiinnittyvää läsnäoloa, myös ajan ja tapahtumien virran kokemista, ja kirjoittamalla tämä mennyt tuodaan tähän aikaan sillä tiedollisella ja tarinallisella osaamisella, joka tutkijalla on. Etnografinen narratiivi ei kuitenkaan tarjoudu koherenttina kokonaisuutena lukijalle, vaan siinä ilmenee jälkiä monenlaisista ajallisista kerrostumista ja myös ajallista katkonaisuutta, jonka lukija voi itse kuroa umpeen kerronnallisten työkalujensa avulla.

\section{Kirjallisuus}

Atkinson, Paul. 1992. Understanding Ethnographic Texts. Newsbury Park, Lontoo ja New Delhi: SAGE Publications.

Bagayoko, Sidylamine ja Sanna Tawah. 2014. "Vallankäyttöä linssin edessä ja takana: visuaalinen etnografia ja kaksi tutkimusta Länsi-Afrikasta." Teoksessa Moniulotteinen etnografia, toimittaneet Pilvi Hämeenaho ja Eerika Koskinen-Koivisto, 185-211. Helsinki: Ethnos ry.

Clifford, James ja George E. Marcus (toim.). 1986. Writing Culture: The Poetics and Politics of Ethnography. Berkeley, Los Angeles ja Lontoo: University of California Press. https://doi. org/10.1177/0308275x8700700104

Coffey, Amanda. 1999. The Ethnographic Self: Fieldwork and the Representation of Identity. Lontoo, Thousand Oaks ja New Delhi: SAGE Publications.

Elliott, Danielle ja Dara Culhane (toim.). 2017. A Different Kind of Ethnography. Toronto: University of Toronto Press.

Fingerroos, Outi. 2003. "Refleksiivinen paikantaminen kulttuurien tutkimuksessa." Elore 10(2). https://doi.org/10.30666/elore.78407

Frank, ArthurW.1997.TheWounded Storyteller:Body, Illness, andEthics.SecondEdition.Chicago: University of Chicago Press. https://doi.org/10.7208/chicago/9780226067360.001.0001

Geertz, Clifford. 1988. Works and Lives: The Anthropologist as Author. Palo Alto: Stanford University Press. 
Gould, Jeremy. 2016. "Refleksiivisyyden poluilla: Epistemologisesti radikaalin yhteiskuntatieteen puolustus." Teoksessa Tutkija peilin edessä: Refleksiivisyys ja etnografinen tieto, toimittaneet Jeremy Gould ja Katja Uusihakala, 9-37. Helsinki: Gaudeamus. https://doi.org/10.1111/1469-8676.12445

Hallila, Mika. 2008. "Kertomus, aika ja ihminen: Paul Ricoeurin Temps et récit ja jälkiklassinen narratologia". Avain 5(3): 22-37. https://doi.org/10.30665/av.74738

Haraway, Donna. 1991. Simians, Cyborgs, and Women: The Reinvention of Nature. New York: Routledge. https://doi.org/10.14361/9783839413272-086

van Hulst, Merlijn. 2020. "Ethnography and narrative." Policing and Society 30(1): 98-115.

Hägg, Samuli. 2010. "Narratologisten käsitteiden soveltaminen kulttuurintutkimuksessa." Teoksessa Vaeltavat metodit, toimittaneet Jyrki Pöysä, Helmi Järviluoma ja Sinikka Vakimo, 117-137. Joensuu: Suomen Kansantiedon Tutkijain Seura.

Hämeenaho, Pilvi ja Eerika Koskinen-Koivisto. 2014. "Etnografian ulottuvuudet ja mahdollisuudet." Teoksessa Moniulotteinen etnografia, toimittaneet Pilvi Hämeenaho ja Eerika Koskinen-Koivisto, 7-31. Helsinki: Ethnos ry. https://doi.org/10.30666/ elore.79119

Koski, Kaarina. 2007. "Mikä kertomus on? Tieteidenvälisyyden haasteita 'kertomusten' tarkastelussa." Elore 14(1). https://doi.org/10.30666/elore.78633

Raunola, Ilona. 2010. "Osallisuus ja dialoginen paikantuminen etnografisessa kenttätyössä." Teoksessa Vaeltavat metodit, toimittaneet Jyrki Pöysä, Helmi Järviluoma ja Sinikka Vakimo, 285-314. Joensuu: Suomen Kansantietouden Tutkijain Seura.

Ricœur, Paul. 1984. Time and Narrative. Volume 1, kääntäneet Kathleen Blamey ja David Pellauer. Chicago ja Lontoo: University of Chicago Press.

Ricœur, Paul. 1991. A Ricoeur Reader: Reflection and Imagination. Toronto: University of Toronto Press.

Saariluoma, Liisa. 1998. "Saatteeksi". Teoksessa Interteksti ja konteksti, toimittaneet Liisa Saariluoma ja Marja-Leena Hakkarainen, 7-12. Helsinki: Suomalaisen Kirjallisuuden Seura.

Saresma, Tuija. 2007. Omaelämäkerran rajapinnoilla: Kuolema ja kirjoitus. Jyväskylä: Jyväskylän yliopisto.

Silvasti, Tiina. 2001. Talonpojan elämä: Tutkimus elämäntapaa jäsentävistä kulttuurisista malleista. Helsinki: Suomalaisen Kirjallisuuden Seura.

Tiili, Miia-Leena. 2016. Ammattilaisuuden ankkuripaikat: Kinesteettinen ja kulttuurinen tieto Suomenlahden merivartiostossa. Helsinki: Helsingin yliopisto.

Turner, Mike. 1996. The Literary Mind. Oxford ja New York: Oxford University Press.

Ukkonen, Taina. 2003. "Kertomisen voima." Elore 10(2). https://doi.org/10.30666/elore.78416

Van Maanen, John. 1988. Tales of the Field. Chicago: University of Chicago Press.

Wiik, Richard. 2011. "Reflections on Orderly and Disorderly Ethnography." Ethnologia Europaea 42(1): 60-76. https://doi.org/10.16995/ee.1074

FM Eino Heikkilä on kansatieteilijä ja väitöskirjatutkija Helsingin yliopistosta. Heikkilän väitöskirja käsittelee tutkijasubjektin merkitystä ja narratiivista tiedontuotantoa etnografisessa tutkimustekstissä. 